\title{
INTERNAL AUDITING QUALITY AND EARNINGS MANAGEMENT: EVIDENCE FROM SULTANATE OF OMAN
}

\author{
Hind Juma Alyaarubi', Dua Said Alkindi', Essia Ries Ahmed1, * \\ ${ }^{1}$ College of Economics, Management and Information Systems, University of Nizwa, Oman
}

ABSTRACT - The main purpose of this research is to determine the link between internal auditing quality and earnings management in Omani companies. In this research, a sample size of 80 was designated from two sectors (Industrial, and Service) in Muscat Securities Market (MSM) in Sultanate of Oman. The secondary data collected is examined with Smart PLS 3.0. The findings of the research show a positive link between Internal audit quality and earnings management in both sectors (industrial and service). This finding indicates that the increase in audit quality will affect to enhance and improve the earning management in Omani listed firms.

\author{
ARTICLE HISTORY \\ Received: $10-2-2021$ \\ Revised: $19-4-2021$ \\ Accepted: $17-5-2021$

\section{KEYWORDS} \\ Internal Auditing Quality, \\ Earning Management, \\ Oman
}

\section{INTRODUCTION}

Earnings management findings from an estimate in financial reporting with the intent of either deceptive stakeholders about a firm's profitability or may affect contractual outcomes that are based on accounting numbers (Putra, \& FitoMela, 2019). Earnings management is an alternative that is used to manipulate profits are reported for certain purposes (Jordan, Clark, \& Hames, 2010). Ronen and Yaari (2008) defined earnings management as "a collection of managerial decisions that result in not reporting the true short-term, value-maximizing earnings as known to management". Earnings management leads to a higher necessity for auditors. An auditor is required to give assurance work that financial data can be reliable for making-decision. The significance of auditing revolves around how the earnings are disclosed in the company, and as we are aware in the previous and contemporary years, that income administration has spread widely around the world (Hashim, Ahmed \& Huey, 2019; Ahmed, Alabdullah, Shaharudin, \& Putri, 2020). Where agencies evaluated by using their overall performance in the quick-term and lengthy period linked to how they control their earnings (Hashim, Ries, \& Huai, 2019; Ibrahim, Mansor \& Ahmad, 2020). Consequently, the corporate governance mechanisms lie by enticing the auditor. The auditor should have labored high-quality management to minimize deceptive income (Alabdullah, \& Ahmed, 2020; Flayyih et al., 2018). Earning administration is one of the most serious troubles going through company effectiveness. Poor management of earnings leads to loss of credibility of stakeholders or organization owners, and this leads to poor outcomes such as loss of confidence (Flayyih et al., 2018).

Auditing is the main factor in financial stability and trust and market confidence (Alabdullah, \& Ahmed, 2020). The law gives auditors the responsibility to conduct statutory audits and play an important role in providing legal services opinions on whether the financial statements are true and fair (Nwoye, Anichebe \& Osegbue, 2020). There are several scandals that interior audit and earnings administration organizations are uncovered to which lead unfold of accounting problems, which have failed to deal with corporations via the incorrect preference. Besides, as we have observed in the past and present-day years that income administration has unfolded extensively around the world. The firms are evaluated via their brief and lengthy-time period overall performance concerning how they manipulate their profits. Thus, the company governance mechanisms lie in the involvement of the auditor (Nwoye et al., 2020).

For example, WeWork of this organization suffered many losses. In 2016, the business enterprise generated \$ 429 million in the income of $\$ 436$ million, and the company's losses lasted for years. In 2019, the employer declared financial ruin of $\$ 690$ million, well worth $\$ 1.5$ billion, and the purpose for these losses is that the employer used to be now not correctly managed (Jessica, 2020). Many organizations are no longer managing their income properly or tampering with their performance. Moreover, it led to the fall down of this business enterprise and different organizations to issues and criticisms of the inner audit and assumed that the researchers purpose to learn about the relationship, the great of income, and components of the companies (Jessica, 2020). Accrual accounting and evaluation suggest that large audit committees with larger independence are extra in all likelihood to correlate with the fantastic of earnings in industrial companies in the GCC (Ahmed, et al., 2020; Alabdullah, Ahmed \& Abushammala 2020). Also, does the best of interior auditing contribute to limiting deceptive income in the workplace model (Hamdan, 2020).

Auditing is an important contributor to monetary constancy, re-establishment of the company, and market and consumer confidence (Alabdullah, \& Ahmed, 2020). Also, whether or not the economic records and income introduced are actual or manipulative. The company accounting scandals in Oman have aroused its activity in auditing for their integrity and the exceptional of economic data (Nwoye et al., 2020). A quantity of research has clarified the relationship between audit exceptional and earnings administration in Oman. Based on that, a set of the problems, troubles, and doubts 
confronted of Oman, including: (1. Losing audit quality is one of its secondary goals to reveal its true profits. 2. The positive and negative impact of audits on companies and investors. 3. How to manage profits, divide benefits, and perform profit manipulation in insurance companies. 4. The effect of company size on earning management. 5.The corporate governance structure and the relationship of managers to investors has a great relationship with the quality of auditing and the method of disclosure of profits. 6. Lack of competence and experience with the audit committee on how to improve and manage companies' profits in Oman.

\section{CRITICAL REVIEW OF THE LITERATURE}

In the early 1990s, company governance was once first introduced; And since that time, it has been used broadly till current years, the significance of the governance regulation lies in the correct compliance of organizations through the fine of interior auditing and its relevance to how companies are managed (Ahmed, Alabdullah, \& Shaharudin, 2020; Flayyih, Ali, \& Mohammed, 2018). This governance is carried out by using special mechanisms from one company to some other notwithstanding the existence of steady legal guidelines and regulations (Flayyih et al., 2018).

This study will focus on the previous studies in the last five years. The majority of studies found that the internal auditing quality impacts earnings management. For example, Elghuweel, Ntim, Opong, and Avison, (2017) examined the impact of internal audits on effective company governance in industrial banks in Oman. This study found a big positive relationship between internal audits and effective company governance. Gebrayel, Jarrar, Salloum, and Lefebvre, (2018) examined the impact of the audit committee and also the presence of internal audit operate on a company's money coverage quality. They mentioned that the inner audit operation is taken into account as a crucial company governance mechanism to safeguard the standard of economic coverage. In that, this will be via observance structure risks, assessing internal controls, and detective work doable manipulation as a result of the inner auditor evaluates money procedures. However, results counsel that the connection between different company governance mechanisms and money coverage quality isn't important. Alareeni, (2018) they have study the considers of information for listed firms in GCC countries to decide whether or not firms apply earnings management (EM). Further, they examine the impact of a group of firmspecific characteristics (company size, advantage, and losses) on EM practices. The results of the study are also of interest to completely different components like auditors, banks, credit establishments, and every one budget users generally. Further, it helps governments in setting rules and procedures to safeguard the interest of shareholders in GCC countries. Since it offers a transparent image of the sort of EM practices in GCC countries. Alhebri, and Al-Duais, (2020) examined the step-up earnings management (AEM) and real earnings management (REM) in family businesses (FB) in the Asian country. Current literature indicates that the dominant shareholders during business surroundings weak to shield investors confiscate minority rights. The results thus indicate that earnings declared in Saudi family businesses' monetary statements square measure less reliable. Regulators and policy manufacturers ought to think about the findings, that family-controlled corporation's square measure able to manipulate earnings. Sanad,Shiwakoti, and Kukreja, (2019) examine four audit committee characteristics together with the audit committee independence, size of the audit committee, audit committee diligence, and financial expertise of the audit committee members. They try to spot if any of those characteristics deferentially impact the earnings political theory.

Sanad,Shiwakoti and Kukreja, (2019) additionally realize that the audit committee diligence has no impact on earnings ideology. Alam, Ramachandran, and Nahomy, (2020) examined the impact of the Board characteristics, chief Executive officer's (CEO) power, and law supervising on earnings management (EM) inside typical and Islamic banks. Results of study area unit vital in deliberating that the word 'Islamic' should not be used just as a profit manifestation. However instead should promote a value-based business, that successively may guarantee dependableness and property. Lestari, and Hanifah, (2020) mentioned the impact of company governance (CG) and money holdings (CH) on earnings quality and also the implication on firm price. They anticipate that earnings quality mediates the impact of $\mathrm{CG}$ and $\mathrm{CH}$ on firm price. However, Banks with sensible CG have lower earnings quality, and banks with high $\mathrm{CH}$ show higher earnings quality. Solely CG that features a vital result on firm price with negative direction. They didn't realize the mediating result from each variable. Elsiddig Ahmed, (2020) examined the operationalize monetary coverage quality in terms of the qualitative characteristics (QCs) as declared by the accounting and auditing organization of monotheism monetary establishments (AAOIFI) standards. Yet on investigating their association with earnings quality (EQ) and banking performance. However, there's no important relationship between combining weight and comprehensibility and there's a big negative relationship between combining weight and comparison. Moreover, they found a significant positive relationship between combining weight and ROA on one hand, combining weight and ROE on the opposite. Ibrahim, Mansor, and Ahmad, (2020) examined the internal audit committee is chargeable for the link between company audited account and actual financial gain management of Nigerian listed non-financial firms. The survey results show that internal audit the committee mediates the link between the company's audited account and actual revenue management. The analysis showed audit fees and complete auditors have a positive impact on the standard of financial gain, whereas the audit tenure is a smaller amount effectively forestall actual profit manipulation. The survey results conjointly showed that the corporate found to be tiny in size and advantage laid low with the standard of financial gain have to be compelled to place nice stress on mistreatment the independence of the higher-up audit committee among non-financial firms listed in the African country. Flayyih, Ali, and Mohammed, (2018) have study the results of the board of administrators, the audit committee, and concentration possession as company governance mechanisms in managing results. They examined additionally to analyze the role of audit quality within the partnership between company governance and revenue management of banks listed on the Iraqi securities market. The findings showed that the audit has a bearing on the five 
parameters thought about underneath the results of company governance in earnings management. Jessica, (2020) mentioned the influence of company characteristics and sensible governance characteristics of the behavior of profit management. The investigation finds that the firm options will intensify earnings management behavior considerably. On the opposite hand, in sensible company condition governance characteristics solely the auditor of the massive four important. Yasser and Soliman, (2018) examined to see the impact of the standard of the audit on earnings management in insurance firms with special thought of accruals and performance measures of earnings manipulations mistreatment insurance firms in Nigeria. The result shows that the standard of the audit had a major impact on earnings management. Almarayeh, Aibar-Guzmán, and Abdullatif, (2020) examined if its bound audit quality attributes are capable of limiting earnings management. In an exceedingly developing country, the findings are according to the expectation that in rising countries external audits could perform otherwise. Then in Anglo-Saxon and Western Europe with relevancy its role in limiting profit management and indicates that given the institutional surroundings in Jordan, the dimensions of the auditor and the audit fees don't have a significant impact on earnings management. Alareeni, (2018) this study to determine whether firms listed in GCC countries; follow earnings management (EM). What is more, the impact of a collection of the particular characteristics of the corporate square measure examined within the EM practices. The results show that company size and leverage have a negligible impact on rising market practices within the GCC countries. Company losses have an effect on rising markets in GCC countries except for Bahrain. This is often additional proof confirming that almost all GCC countries square measure concerned in EM and follow earning management through decreasing financial gain discretion accumulations.

Amrah, and Obaid, (2019) examined the connection between company governance effectiveness and money reportage quality among family and non-family owned firms within the country of Asian countries. The empirical results indicate that the association between company governance effectiveness and its financial reportage quality is positive and vital for each, the complete sample furthermore, because the non-family corporations. However, this relationship seems to be weaker for family-owned corporations. Baatwah, Salleh, and Ahmad, (2018) mentioned exploring the distinctive setting of Oman with relevancy audit quality. Additionally, they measure the standard of an audit by examining whether or not big-four audit companies and trade specialist auditors have a job in raising the standard of the audit. They found the various from previous studies as a result of it's the primary to comprehensively examine audit quality during a distinctive setting the gulf cooperation council (GCC). Also, it extends our understanding of the role of religiousism in audit quality. Lassoued, Attia, and Sassi, (2018) this study examines to check earnings management between typical and Islamic banks and look at whether or not possession structure affects earnings management within the industry of rising markets. As the result, institutional homeowners encourage earnings management in Islamic banks and State participation will increase earnings management in typical banks. Finally, family homeowners scale back this observe in each sort of bank. HassanOMER, Aljaaidi, and Habtoor, (2020) prompt to research the link of board quality, audit quality, and audit report lag on firm performance of factory-made Saudi's listed firms. The framework of the study is developed supported the predictions of agency theory and resource dependence theory that board quality, audit quality, and audit report lag area unit related to the firm performance. This study proposes that they ought to emphasize a lot on enhancing the role and therefore the quality of their board of administrators and therefore the audit quality problems, as this sweetening could influence their performance. Awadallah, (2020) they have study recent world monetary scandals that have a diode to a variety of investigations into the effectiveness of company governance. Though proof exists from developed economies, terribly scanty studies are conducted in rising economies wherever company governance is simply evolving. The results additionally indicate that institutional investors and social control possession don't have any important impact on audit quality. Also, the dimensions of the corporate, together with business complexness and leverage are poignant audit quality.

\section{The relationship between Internal Auditing Quality and Earning Management}

Putra, and FitoMela, (2019) found that the high audit quality will increase informative earnings management and decrease opportunist earnings management. Jordan, et al., (2010) findings suggest that audit quality significantly restricts management's attempts at roundup earnings per share. Oyebamiji (2020) the research found that audit quality had an inverse and significant impact on earnings management practices among listed firms in Nigeria. Inayah and Prasetyo (2021) the study found that there is a significant negative impact on the auditor's specialization moderated by the audit board with earnings management. Tajudeen (2020) this study found that audit quality has a significant effect on the earnings management of listed manufacturing firms in Nigeria. Rahmawati, (2020) the findings of this study showed that audit quality has a positive and significant effect on earnings management in Indonesia. Elghuweel et al., (2017) this study found a significant positive relationship between internal audits and effective company governance.

Alareeni, (2018) the results of the study mentioned that offer a transparent image of the sort of earning management practices in GCC countries. Flayyih et al., (2018) findings showed that the audit has a bearing on the five parameters thought about underneath the findings of corporate governance in earnings management. Yasser and Soliman, (2018) the result show that the quality of the audit had a significant effect on earnings management. Widagdo, Rahmawati, Murni, Wulandari, and Agustiningsih,

(2021) they found that the audit quality had a significant impact on the behavior of earnings management. Thus, the hypothesis developed is:

$\mathrm{H} 1$ : A positive relation between internal auditing quality and earning management. 


\section{RESEARCH METHODOLOGY}

This is a cross-sectional study using quantitative methods, in which quantitative data is collected through ancillary data. The dependent variable in this study was the earning management in the company's annual reports. In this study, the sample size will be 80 companies from two sectors (Industrial and Service) we select this two sectors because it is very important in Oman. The industrial sector is taken into account as one of the most engines of economic and social development within the Sultanate of Oman because it is one of the foremost vital means that of achieving economic diversification and property development. Additionally, the services sector plays an important role within the promising fashionable Omani economy. Therefore, the development of sectors is an important component in achieving the microfoundations of wealth creation and economic development of the Sultanate of Oman. So, manufacturing and service activities have become an essential component in achieving high efficient growth, and is necessary to determine which should be invested and developed further. A more efficient manufacturing sector can be formulated by the use of knowledge, technology, and physical capital which outcome in achieving a much efficient service sector (Al-Mawali, Al Lawati, \& Ananda, 2019). This is often necessary to extend investment, non-oil exports, and also the aggressiveness of Oman. The analysis units of this study were the annual reports of the companies listed on the Muscat Securities Market (MSM). Industrial firms and service firms for the year 2019. The annual report has been used extensively to test the company's benefit earning management.

\section{Measurement of Variables}

The current study utilized a specific of measurements in order to measure its chosen variables that lie in internal auditing quality and earning management. The explanation of all variable in this table:

Table 1: Summary of variables measurements

\begin{tabular}{lcl}
\hline \multicolumn{1}{c}{ Variables } & Acronym & \multicolumn{1}{c}{ Description } \\
\hline Audit Fees & AF & The log Percentage of the amount paid as audit fees. \\
Audit Committee Meetings & AC-M & $\begin{array}{l}\text { The variable was measured through the number of annual meeting the } \\
\text { committee hold. }\end{array}$ \\
Audit Committee Size & AC-Z & $\begin{array}{l}\text { The number of audit committee. } \\
\text { It is measured in absolute terms of residual (estimated maturities) } \\
\text { Earning Management }\end{array}$ \\
& EM & Kumai, 2015).
\end{tabular}

Earning Management Measurement: The study variables consist of a dependent variable which is earnings which is the quality of earnings measured by discretionary accruals using the modified Jones model by Dechow et al. (1995). This was done by performing the analysis in two stages- first extracting the residues from the modified Jones form and then running the regression using the study model. Also, The independent variables internal audit quality, audit committee meetings, and audit committee size.

\section{Industrial Sector (Descriptive Statistics)}

Based on the results of the descriptive statistics, the dependent variable, which is earning management, displayed that the level of earning management was 3.094 showing the average of earning management, with a standard deviation of 1.770. Furthermore, the minimum and maximum values indicated that EM is 0.800 and 6.980 respectively. Also, the descriptive analysis for determinants shows that audit quality has an average of 3.517with a standard deviation of 1.822 ; the audit committee meetings have an average of 5.125 with a standard deviation of 2.027; the audit committee size has an average of 5.225 with a standard deviation of 1.768 .

Table 2: Descriptive Statistics of variables

\begin{tabular}{lcccc}
\hline & Mean & Minimum & Maximum & Standard-D \\
\hline Internal Audit Quality & 3.517 & 0.300 & 7.700 & 1.822 \\
Audit Committee Meetings & 5.125 & 1.000 & 11.000 & 2.027 \\
Audit Committee Size & 5.225 & 3.000 & 9.000 & 1.768 \\
EM & 3.094 & 0.800 & 6.980 & 1.770
\end{tabular}




\section{Discriminant Validity}

In PLS for testing the discriminant validity, there are standards applied. The square root of each AVE for each construct should have a high correlation level as well as the opposite constructs. Thus, to manage discriminant validity, as mentioned by Fornell \& Larcker (1981), the square root of every construct in its AVE has got to be compared versus the constructs' correlations for all different constructs.

Table 3: Discriminant Validity Constructs

\begin{tabular}{lcccc}
\hline & AC-M & AC-Z & EM & AQ \\
\hline AC-M & 1.000 & & & \\
AC-Z & 0.306 & 1.000 & & \\
EM & 0.431 & 0.122 & 1.000 & \\
IAQ & 0.329 & 0.121 & 0.675 & 1.000
\end{tabular}

Structural-model analysis conducted was done once analysis the measuring model and it's passed all criteria. An associate examination of the determination coefficient $\left(\mathrm{R}^{2}\right)$ is completed. During this work, a variable that is that the endogenous show to own $\mathrm{R}^{2}$ value $0.505,0.463$. Earning management (substantial) suggesting that 50\%, 46\% of the variance in earning management will be explained by the predictors: (Internal Audit Quality, Audit Committee Meeting, and Audit Committee Size). So, the current work greatly meets the quality.

Table 4: Explanation of the Variance

\begin{tabular}{lcc}
\hline Matrix & R Square & R Square A \\
\hline EM & 0.505 & 0.463
\end{tabular}

\section{Service Sector (Descriptive Statistics)}

Based on the results of the descriptive statistics, the dependent variable, which is earning management of the company, showed that the level of earning management was 3.694 representing the average of earning management, with a standard deviation of 1.919. Furthermore, the minimum and maximum values indicated that earning management is 1.050 and 7.630 respectively. Also, the descriptive analysis for determinants shows that internal audit quality has an average of 3.675 with a standard deviation of 1.774; the audit committee meetings have an average of 5.361 with a standard deviation of 1.619; the audit committee size has an average of 6.222 with a standard deviation of 2.225 .

Table 5: Descriptive Statistics of variables

\begin{tabular}{lcccc}
\hline & Mean & Min & Max & Standard-D \\
\hline Internal Audit Quality & 3.675 & 1.100 & 6.600 & 1.774 \\
Audit Committee Meetings & 5.361 & 2.000 & 9.000 & 1.619 \\
Audit Committee Size & 6.222 & 3.000 & 11.000 & 2.225 \\
EM & 3.694 & 1.050 & 7.630 & 1.919
\end{tabular}

\section{Discriminant Validity}

The square root of each AVE for each construct must have a high correlation level including other constructs. The square root of every construct in its AVE must be compared against the constructs' correlations of all other constructs.

Table 6: Discriminant Validity Constructs

\begin{tabular}{lllll}
\hline & AC-M & AC-Z & EM & IAQ \\
\hline AC-M & 1.000 & & & \\
AC-Z & 0.279 & 1.000 & & \\
EM & 0.243 & 0.123 & 1.000 & \\
IAQ & 0.287 & 0.100 & 0.515 & 1.000
\end{tabular}

Evaluation for the Structural-model was done after measurement model analysis and it has passed all criteria. An examination of the determination coefficient $\left(\mathrm{R}^{2}\right)$ is done. In this research, a variable which is the endogenous show to have $\mathrm{R}^{2}$ value $0.278,0.210$ earning management (substantial) suggesting that $27 \%, 21 \%$ of the variance in earning management can be explained by the predictors: (Internal Audit Quality, Audit Committee Meetings and Audit Committee Size). So, the current work highly meets the criterion. 
Table 7: Explanation of the Variance

\begin{tabular}{lcc}
\hline Matrix & R Square & R Square A \\
\hline EM & 0.505 & 0.463
\end{tabular}

\section{HYPOTHESIS TESTING}

Table 8, reviews the results related to the hypothesis testing and finds that the majority of hypotheses are not supported (only one hypothesis supported) the result revealed that the internal auditing quality positively significant with earning management where it was $\mathrm{P}<0.000, \mathrm{t}=6.280$. This result indicates that an internal auditing quality has a significant impact on earning management. The findings showed that audit committee size negative with the significant earning management where it was $\mathrm{P}<0.851, \mathrm{t}=0.188$. This result indicates that the audit committee size has no significant impact on earning management. The result showed that audit committee meetings negatively significant with earning management where it was $\mathrm{P}<0.157, \mathrm{t}=0.1 .418$. This result indicates that the audit committee meetings have no significant impact on earning management.

Table 8: Path Coefficients

\begin{tabular}{lrcccc}
\hline & $\begin{array}{r}\text { Origin } \\
\text { al Sample }\end{array}$ & $\begin{array}{c}\text { Sample } \\
\text { Mean }(\mathrm{M})\end{array}$ & $\begin{array}{c}\text { Standard } \\
\text { Deviation }\end{array}$ & $\begin{array}{c}\text { T Statistics } \\
(\text { O/STDEV) }\end{array}$ & P Values \\
\hline AC-M - > EM & 0.241 & 0.257 & 0.170 & 1.418 & 0.157 \\
AC-Z - > EM & -0.024 & -0.029 & 0.129 & 0.188 & 0.851 \\
IAQ - > EM & 0.598 & 0.589 & 0.095 & 6.280 & 0.000
\end{tabular}

Note: Significance levels: $* * * \mathrm{P}<0.001(\mathrm{t}>3.33),{ }^{*} \mathrm{p}<0.01(\mathrm{t}>2.33),{ }^{*} \mathrm{p}<0.05(\mathrm{t}>1.605)$

Table 9, reviews the results for hypothesis testing and finds that the majority of the hypotheses are not supported (Support only one hypothesis) the results presented that the internal auditing quality positively significant with earning management where it was $\mathrm{P}<0.003, \mathrm{t}=3.017$. This result indicates that the internal auditing quality has a positive impact on earning management. The findings showed that audit committee size negative with the significance with earning management where it was $\mathrm{P}<0.752, \mathrm{t}=0.317$. This result indicates that the audit committee size has no significant impact on earning management. The results showed that audit committee meetings negatively significant with earning management where it was $\mathrm{P}<0.549, \mathrm{t}=0.600$. This result indicates that the audit committee meetings have no significant impact on earning management.

Table 9: Path Coefficients

\begin{tabular}{lccccc}
\hline & $\begin{array}{c}\text { Origin } \\
\text { al Sample }\end{array}$ & $\begin{array}{c}\text { Sample } \\
\text { Mean }(\mathrm{M})\end{array}$ & $\begin{array}{c}\text { Standard } \\
\text { Deviation }\end{array}$ & $\begin{array}{c}\text { T Statistics } \\
\text { (O/STDEV) }\end{array}$ & P Values \\
\hline AC-M - > EM & 0.090 & 0.107 & 0.150 & 0.600 & 0.549 \\
AC -Z > EM & 0.050 & 0.040 & 0.157 & 0.317 & 0.752 \\
IAQ - > EM & 0.485 & 0.471 & 0.161 & 3.017 & 0.003
\end{tabular}

Note: Significance levels: $* * * \mathrm{P}<0.001(\mathrm{t}>3.33),{ }^{*} \mathrm{p}<0.01(\mathrm{t}>2.33),{ }^{*} \mathrm{p}<0.05(\mathrm{t}>1.605)$

\section{IMPACT OF INTERNAL AUDITING QUALITY ON EARNING MANAGEMENT}

The basic key of this study to determine the relationship between internal auditing quality and earning management in the Muscat Securities Market in the Sultanate of Oman. Subsequently, the research aims to analyze and perceive the impact of internal auditing quality on earning management in Oman. Within the previous literature review, this analysis determines 3 variables that influence the earning management were the independent variables that area unit internal auditing quality (Internal Audit Quality, Number of Audit Committee Meeting, and Audit Committee Size). From all freelance variables that area unit is known, hypotheses were fashioned to inquire regarding the target. The analysis used quantitative knowledge to be obtained from two sectors. A total of 80 out of 116 firms (industrial sector and service sector) were with success collected during this research.

One of the independent variables associated with internal auditing quality and earning management is audit quality. In the industrial sector, the results show a positive link between internal audit quality and earning management $(\mathrm{p}<0.05$, $\mathrm{t}=6.280$ ). This indicates that the earning management is significantly influenced by internal audit quality, it implies that the audit committee has done adequate internal audit quality, while an inadequate number of auditing reports implies a lack of auditors involvement to conduct or report audit findings. Therefore, the association of quality audits with monitoring earning management and will ensure stakeholders' confidence remain high. Also, in the services sector show a significant positive among the internal audit quality and earning management $(\mathrm{p}<0.05, \mathrm{t}=3.017)$, the hypothesis is supported in both sectors. This fact indicates that the increase in audit quality will affect increase the control of earning management in Omani-listed firms. This finding is related to the previous study of Elghuweel et al., (2017) as found a 
big positive relationship between internal audit and effective internal control tools. Also, in another study done by Yasser and Soliman, (2018) the result shows that the quality of the audit had a significant effect on earnings management.

The results show a negative insignificant link between the audit committee meeting and earning management. In industrial sector was $(\mathrm{p}<0.05, \mathrm{t}=0.1 .418)$ and in-service sector $(\mathrm{p}<0.05, \mathrm{t}=0.600)$. This finding agrees with the previous study of Gebraye et al., (2018) They mentioned that the internal audit operate is taken into account a crucial company governance mechanism to safeguard the standard of economic coverage by observance structure risks, assessing internal controls and detective work doable manipulation as a result of the internal auditor evaluates financial procedures. However, results counsel that the connection between different company governance mechanisms and financial coverage quality isn't important. Flayyih et al., (2018 The findings showed that the audit has a bearing on the five parameters thought about underneath the results of company governance in earnings management.

The findings show an insignificant and negative link between audit committee size and earning management in the industrial sector $(\mathrm{P}<0.05, \mathrm{t}=0.188)$ and in-service sector $(\mathrm{P}<0.05, \mathrm{t}=0.317)$, the hypothesis is not supported. This fact indicates that the if audit committee size higher, will be the control of earning management also higher in Omani-listed firms. This finding is not consistent with the previous study of Almarayeh ., et al (2020) the findings are according to the expectation that in rising countries audit could perform otherwise. Then in Anglo-Saxon and Western Europe with relevancy its role in limiting profit management and indicates that given the institutional surroundings in Jordan, the dimensions of the auditor and also the audit fees don't have a significant impact on earnings management. Also, Zuo and Guan (2014) examined on the association of audit firm size and trade specialization on earnings management in China concludes that audit firm size is considerably negatively associated with earnings management, particularly for corporations with income-increasing abnormal accruals.

\section{Recommendation}

This study contains many recommendations for future studies. First, this study examined the direct relationship between internal auditing quality and earning management. This study deals with the direct relationship between internal audit quality and earnings management. There is a lack of previous research that studies the impact of other variables on the relationship between the quality of internal audit and earning management, such as the quality of the audit, the audit committee, and the size of the audit committee that would help in improving administrative control over earning. Second, this study recommends conducting future analysis to check the connection between internal audit quality and internal control earning through alternative variables such as skills, knowledge, and other competencies that auditors need to perform their responsibilities. Third, future researchers should examine the relationship between the quality of internal audit and its control over earning management in depth by adding new variables such as transparency and risk. This study also recommends that there be full disclosure of all financial reports and data on the Muscat Securities Market in all service, industrial, and banking sectors. Fourthly, a Study of the relationship between internal audit quality and joint management control results showed that company owners have expressed independence and scope of work in performing internal auditing, and internal auditors considered that cooperation between internal audit processes is limited, and it appeared to be more positive about cooperation and of high quality. Fifth, the internal audit has objectivity, competence, and experience in administrative operations, and it has important factors that affect the accreditation decision, and internal audit has a common relationship in management that it lies in professionalism and independence. Sixth, the relationship focuses on having an impact on data, independence and accounting experience in auditing have a complementary effect on internal audit relationships and management companies, and independence is linked more with the experience of accountants to being independent of audit issues.

\section{CONCLUSION}

The main objective of this research is to examine the relationship between internal auditing quality and earning management to improve the profitability of companies in the Sultanate of Oman. This research used three independent variables (internal audit quality, number of committee meetings, and audit committee size) to measure the impact of audit quality on earnings management. The data in this study were collected from industrial and service companies, whose sample size was 80 companies (industrial companies 40, service companies 40) and includes 80 companies in the Muscat Securities market. This study chose the two sectors because they are the most exploited and guaranteed compared to other companies, where we combined the two companies and they are among the strong options that give noticeable progress and play an important and exceptional role, and therefore companies can compete strongly in the country of Oman, and the studies of analysis of companies included in the Muscat Securities market and the use of profits in industrial companies and services was monitored.

The results and statistics of the companies were viewed by searching for results (Internal Audit Quality, Audit Committee Meetings, Audit Committee size) the validity between companies was tested, the criteria applied and a high correlation level was built in the companies to deal with the distinct validity. Also, hypotheses and results emerged to us, positive and negative for the earning management of the companies. Positive results have a great impact on the company, and negative results do not affect the audit of the company only slightly.

This study found that the internal audit quality has shown a positive impact on earning management in sectors (Industrial and Service) that listed companies Sultanate of Oman. Also, this study showed there's a negative and insignificant link between an audit board meeting and earning management. As well as this analysis unconcealed there's a negative and vital link between audit committee size and earning management. The research provides an understanding 
of firms may be affected differently in terms of content, and the quality of the company may increase with an increase in focus on (Internal Audit Quality, Audit Committee Meetings, Audit Committee size) which becomes of great impact in terms of its relevance (Earning management) and which appear positively and represent standards resulting in high positive results in auditing. Auditing has a foundation and effectiveness on distinguishing companies, and studies may have a radical change by extracting models of important interest and high quality and being independent.

\section{REFERENCES}

Ahmed, E. R., Alabdullah, T. T. Y., Shaharudin, M. S., \& Putri, E. (2020). Further Evidence on the Link Between Firm's Control Mechanisms and Firm Financial Performance: Sultanate of Oman. Journal of Governance and Integrity, 4(1), 6-11.

Ahmed, E. R., Alabdullah, T. T. Y., \& Shaharudin, M. S. (2020). Approaches to Control Mechanisms and Their Implications for Companies' Profitability: a Study in UAE. Journal of Accounting Science, 4(2), 11-20.

Alabdullah, T. T. Y., \& Ahmed, E. R. (2020). Audit Committee Impact on Corporate Profitability in Oman Companies: an Auditing and Management Accounting Perspective. Riset Akuntansi dan Keuangan Indonesia, 5(2), 121-128.

Alabdullah, T. T. Y., Ahmed ER \& Abushammala S. (2020). Growth of Companies: Empirical Study of the Companies Listed in Developing Economies. Journal of Accounting Science, 4(2), 1-10.

Alam, N., Ramachandran, J., \& Nahomy, A. H. (2020). The Impact of Corporate Governance and Agency Effect on Earnings Management-A Test of the Dual Banking System. Research in International Business and Finance, 101242.

Alareeni, B. (2018). The impact of firm-specific characteristics on earnings management: evidence from GCC countries. International Journal of Managerial and Financial Accounting, 10(2), 85-104.

Alhebri, A. A., \& Al-Duais, S. D. (2020). Family businesses restrict accrual and real earnings management: Case study in Saudi Arabia. Cogent Business \& Management, 7(1), 1806669.

Almarayeh, T. S., Aibar-Guzmán, B., \& Abdullatif, M. (2020). Does audit quality influence earnings management in emerging markets? Evidence from Jordan: ¿ Influye la calidad de la auditoría en la gestión de resultados en los mercados emergentes? Evidencia de Jordania. Revista de Contabilidad-Spanish Accounting Review, 23(1), 64-74.

Al-Mawali, N, R., a Al Lawati, \& Ananda S. (2019) Diversification of Oman Economy for Sustainable Development: Strategic Issues And Imperatives.College of Banking and Financial Studies.ISBN: 978-99969-824-1-5

Amrah, M. R., \& Obaid, M. M. (2019). Effective corporate governance mechanisms, ownership structure and financial reporting quality: evidence from Oman. Asia-Pacific Management Accounting Journal, 14(3), 121-154.

Awadallah, E. (2020). Measuring the effectiveness of selected corporate governance practices and their implications for audit quality: evidence from Qatar. Afro-Asian Journal of Finance and Accounting, 10(1), 24-47.

Baatwah, S. R., Salleh, Z., \& Ahmad, N. (2018). High-quality auditors vs. high-quality audit: the reality in Oman. Afro-Asian Journal of Finance and Accounting, 8(3), 209-236.

Bala, H., \& Kumai, G. B. (2015). Audit committee characteristics and earnings quality of listed food and beverages firms in Nigeria. International Journal of Accounting, Auditing and Taxation, 2(8), 216-227.

Elghuweel, M. I., Ntim, C. G., Opong, K. K., \& Avison, L. (2017). Corporate governance, Islamic governance and earnings management in Oman. Journal of Accounting in Emerging Economies, 7(2), pp. 190-224.

Elsiddig Ahmed, I. (2020). The qualitative characteristics of accounting information, earnings quality, and Islamic banking performance: Evidence from the gulf banking sector. International Journal of Financial Studies, 8(2), 30.

Flayyih, H. H., Ali, S. I., \& Mohammed, Y. N. (2018). The Effect of Integration of Coroprate Governance Mechanisms and Audit Quality in Earning Management: An Empirical Analysis of Listed Banks in Iraqi Stock Exchange. International Journal of Engineering \& Technology, 7(4.25), 337-344.

Gebrayel, E., Jarrar, H., Salloum, C., \& Lefebvre, Q. (2018). Effective association between audit committees and the internal audit function and its impact on financial reporting quality: Empirical evidence from Omani listed firms. International Journal of Auditing, 22(2), 197-213.

Hashim, F., Ahmed, E. R., \& Huey, Y. M. (2019). Board Diversity and Earning Quality: Examining the Role of Internal Audit as a Moderator. Australasian Accounting, Business and Finance Journal, 13(4), 73-91.

Hashim, F., Ries, E. A., \& Huai, N. T. (2019). Corporate Social Responsibility and Financial Performance: The Case of ASEAN Telecommunications Companies. KnE Social Sciences, 892-913.

Hamdan, A. (2020). The role of the audit committee in improving earnings quality: The case of industrial companies in GCC. Journal of International Studies, 13(2).

HassanOMER, W. K., Aljaaidi, K. S., \& Habtoor, O. S. (2020). Board Quality, Audit Quality and Economic Firm Value: The Case of Manufactured Saudi's Listed Companies. Quality-Access to Success, 21(178).

Ibrahim, G., Mansor, N., \& Ahmad, A. U. (2020) The Mediating Effect of Internal Audit Committee on The Relationship between Firms Financial Audits And Real Earnings Management. International Journal of Scientific \& Technology Research Volume 9, Issue 04, 816-822.

Inayah, J. Z., \& Prasetyo, A. B. (2021). The Effect of Audit Committee Effectiveness and Audit Quality on Earnings Management. Jurnal RAK (Riset Akuntansi Keuangan), 5(2), 96-108.

Jessica, V. (2020). The Effect of firm characteristics and good corporate governance characteristics to earning management behaviors. Journal of Accounting, Finance and Auditing Studies, 6(2), 31-49.

Jordan, C. E., Clark, S. J., \& Hames, C. C. (2010). The impact of audit quality on earnings management to achieve user reference points in EPS. Journal of Applied Business Research (JABR), 26(1).

Lassoued, N., Attia, M. B. R., \& Sassi, H. (2018). Earnings management in islamic and conventional banks: Does ownership structure matter? Evidence from the MENA region. Journal of International Accounting, Auditing and Taxation, 30, 85-105.

Lestari, T., \& Hanifah, I. A. (2020). How Corporate Governance and Cash Holdings Affect Earnings Quality and Firm Value. Trikonomika, 19(1), 16-21.

Nwoye, C. M., Anichebe, A. S., \& Osegbue, I. F. Effect of Audit Quality on Earnings Management in Insurance Companies in Nigeria. Oyebamiji, O. A. (2020). Audit Quality and Earnings Management of Selected Listed Consumer Goods Firms in Nigeria (20072016). Global Journal of Management And Business Research. Volume 20, Issue 2. 
Putra, A., \& FitoMela, N., (2019) Audit Quality And Earnings Management: Informative and Opportunist Perspective. International Journal of Scientific \& Technology Research, Volume 8, Issue 09, PP 1918-1822.

Rahmawati, T. (2020). The Influence of Surplus Free Cash Flow and Audit Quality on Earnings Management. (Jurnal Akuntansi Dan Ekonomi), 5(2), 71-81.

Sanad, Z., Shiwakoti, R., \& Kukreja, G. (2019). The Role of corporate governance in mitigating real earnings management: Literature review. KnE Social Sciences, 173-187.

Tajudeen, T. D. (2020). Firm Characteristics, Audit Quality and Earnings Management of Listed Manufacturing Companies in Nigeria (Doctoral dissertation, Kwara State University (Nigeria)).

Yasser, S., \& Soliman, M. (2018). The effect of audit quality on earnings management in developing countries: The case of Egypt. International Research Journal of Applied Finance, 9(4), 216-231.

Zuo, L., \& Guan, X. (2014). The association of audit firm size and industry specialization on earnings management: evidence in China. The Macrotheme Review, 3(7), 1-21.

\section{ACKNOWLEDGEMENT}

The authors would like to thank the University of Nizwa and Dr. Essia Ries Ahmed which assist to conduct this research.

\section{CONFLICT OF INTEREST}

The author(s), as noted, certify that they have NO affiliations with or involvement in any organisation or agency with any financial interest (such as honoraria; educational grants; participation in speakers' bureaus; membership, jobs, consultancies, stock ownership, or other equity interest; and expert testimony or patent-licensing arrangements), or nonfinancial interest (such as personal or professional relationships, affiliations, expertise or beliefs) in the subject matter or materials addressed in this manuscript.

\section{AUTHORS' BIOGRAPHY}

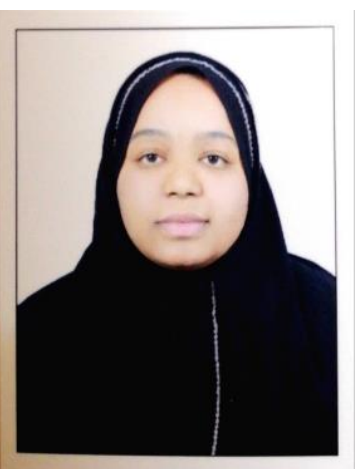

Hind Juma Alyaarubi is a bachelor student in College of Economics, Management and Information Systems, University of Nizwa. The author is interested in auditing, and accounting research areas.

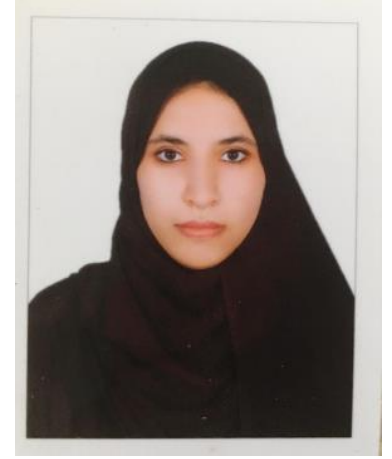

Dua Said Alkindi is a bachelor student in College of Economics, Management and Information Systems (, University of Nizwa. The author is interested in auditing, and accounting research areas. 
Dr. Essia Ries Ahmed is currently working as an assistance of Professor in University of Nizwa. He received his PhD from University Malaysia Perlis (UniMap), master's degree in Accounting from Universiti Sains Malaysia (USM). He has published articles in several Scopus Journals, and proceedings and presented papers at both national and international conferences. Dr. Essia Ries Ahmed is the reviewer and member of editorial board in several journals. 